\title{
Isolation of Chrysosporium indicum from poultry soil for keratinase enzyme, its purification and partial characterization
}

\author{
Jitendra Kumar* \\ Department of Botany, Dolphin (PG) College of Science \& Agriculture, Chunni Kalan \\ Fatehgarh Sahib (Punjab) India \\ Suman Mahal \\ Department of Biotechnology, Dolphin (PG) College of Science \& Agriculture, Chunni Kalan \\ Fatehgarh Sahib (Punjab) India \\ ${ }^{*}$ Corresponding author. Email: jeetmicro@gmail.com
}

\section{Article Info}

https://doi.org/10.31018/ jans.v13i2.2609

Received: March 6, 2021

Revised: June 3, 2021

Accepted: June 9, 2021

\section{How to Cite}

Kumar, J. and Mahal, S. (2021). Isolation of Chrysosporium indicum from poultry soil for keratinase enzyme, its purification and partial characterization. Journal of Applied and Natural Science, 13(2), 744 - 751. https://doi.org/10.31018/jans.v13i2.2609

\begin{abstract}
Keratinases are produced by microorganisms as fungi, actinomycetes and bacteria and have the capacity to degrade tough insoluble keratin proteins, including feathers. Feathers are waste produced from the poultry industry worldwide and accumulated as solid waste. Therefore, keratinolytic fungal strains Chrysosporium indicum were isolated by hair baiting method from poultry farm soil of Punjab, India. Isolated C. indicum were screened for proteolytic activity on skimmed milk agar. Field Emission Scanning Electron Microscopy (FeSEM) analysis confirmed morphological characters as C. indicum. Fourier transform infrared spectroscopy analysis was studied for the structural and mechanism analysis of feather degraded during keratinase production. Keratinase enzyme was purified $48.03 \%$ recovery by ammonium sulphate precipitation, dialysis for desalting and chromatography. Diethylaminoethyl sepharose (DEAE sepharose) and Sephadex-G75 column were used to perform chromatography and partial characterization of the keratinase for temperature, $\mathrm{pH}$, and substrate. The maximum keratinase activity was observed at $50^{\circ} \mathrm{C}$, at $\mathrm{pH} 10$. The maximum enzyme activity of $289.1 \mathrm{U} / \mathrm{ml}$ was observed with keratin powder as substrate and minimum enzyme activity $67.1 \mathrm{U} / \mathrm{ml}$ with keratin azure. This is the first report on the purification and characterization of keratinase by $C$. indicum using DEAE sepharose as affinity chromatography for the purification of the keratinase enzyme.
\end{abstract}

Keywords: Chrysosporium indicum, Fourier transform infrared spectroscopy, Keratinase, Purification, Scanning electron microscopy

\section{INTRODUCTION}

Keratins are insoluble molecules that comprise long polypeptide chains resistant to non-substrate specific proteases (Allpress et al., 2002). Keratins belong to the scleroprotein group of fibrous family, which is found in feather, wool, horn nails (Kumar et al., 2021). Keratinases are serine or metalloproteases proficient of degrading the structure forming keratinous proteins which cannot be solubilized completely by the purified keratinases (Ramnani et al., 2005). Keratinase produced by keratin degrading microorganism as bacteria, actinomycetes and fungi (Kumar and Kushwaha, 2014). Several reports are available on isolation and screening of microorganism for keratinase production Streptomyces (Ya-peng et al., 2007), fungi (Kumar and Kushwaha 2014). Optimization of growth media and cultural condi- tions by bacteria Bacillus licheniformis was studied (Gupta and Ramnani, 2004, Cai et al., 2008, Kainoor and Naik 2010), Bacillus sp. (Kanchana et al., 2012), (Mehta et al., 2014), Acremonium strictum (Kumar and Kushwaha 2012). Few reports are available on purification and characterization of keratinase enzyme produced by microorganisms Lysobacter sp. (Allpress et al., 2002), Bacillus licheniformis (Suntornsuk et al., 2005), Bacillus thrungenesis (Sivakumar 2012), Streptomyces albus (Esawy 2007), Microsporum gypseum (Raju et al., 2007), Trichophyton simmi (Singh 1997), Aspergillus parasiticus (Anitha and Palanivelu, 2012), Cunnighamella echinulata (More et al., 2013). However most of the study belong to bacterial isolates or dermatophytes, therefore the purification and characterization of keratinase from nonpathogenic microorganisms is important because of their capacity to degrade the ker- 
atin and various application. Keratinase could be useful into development of economically feather meal (Onifade et al., 1998, Lin et al., 1999), nitrogenous fertilizer, biodegradable films, glues foils (Friedrich and Antranikian 1996, Schrooyen et al., 2001, De Toni et al., 2002, Gupta and Ramnani 2006), prion degradation (Langeveld et al., 2003), feather compost for plant growth enhancement (Kumari and Kumar 2020, Kumar et al., 2020). The objective of the present study was to isolate a potent keratinolytic fungi and to study the purification and characterization of its keratinase enzyme.

\section{MATERIALS AND METHODS}

\section{Isolation and screening and identification of Fungi}

Keratinophilic fungi were isolated by the hair baiting method of Benedek (1962). Soil samples were taken from a poultry farm in Chunni Kalan, Punjab, and placed in Petri plates with sterile water to moisten them. Baits made of chicken feathers were used.

For the primary screening of proteolytic activity, $5 \mathrm{~g} \mathrm{~L}^{-1}$ peptones, $3 \mathrm{~g} \mathrm{~L}^{-1}$ yeast extract, $100 \mathrm{~mL} \mathrm{~L}^{-1}$, sterile UHT nonfat milk, and $12 \mathrm{~g} \mathrm{~L}^{-1}$ agar were used following the method of Riffel and Brandelli (2006). The Fungi were inoculated on skimmed milk agar plates and incubated for $3,6,9$ and 12 days for $28^{\circ} \mathrm{C}$ to observed keratinolytic potential. The diameter of the clearing zone was measured to quantify keratinase enzyme activity.

\section{Morphology of Chrysosporium indicum}

C. indicum was observed by the morphological characters on agar media petri plates simple microscopy in the laboratory. Field Emission Scanning Electron Microscopy (FeSEM) of $C$. indicum at Central instrumentation facility (CIF), Lovely Professional University, Jalandhar $(\mathrm{Pb})$ having a resolution as 1 Micrometer and particle of the size of $100 \mathrm{~nm}$.

\section{FTIR analysis of feather degradation}

Feather degradation by $C$. indicum was studied by FTIR performance which was recorded by using Perklin Elmer spectrum having a resolution of $\mathrm{cm}^{-1}$ and scan range $4000 \mathrm{~cm}^{-1}$ to $250 \mathrm{~cm}^{-1}$ in CIF Lovely Professional University Punjab.

\section{Keratinase production}

Keratinase production media was prepared by the method of Kumar and Kushwaha (2012) by taking $5 \mathrm{~g}$ feather, $2 \mathrm{~g}$ glucose, $5 \mathrm{~g}$ peptone, $5 \mathrm{~g}$ yeast extract, $1 \mathrm{~g}$ $\mathrm{K}_{2} \mathrm{HPO}_{4}, 3 \mathrm{~g} \mathrm{KH}_{2} \mathrm{PO}_{4}, 1 \mathrm{~g} \mathrm{Cacl}_{2}$ and $1 \mathrm{~g} \mathrm{MgSO}_{4}$ dissolved in $1000 \mathrm{ml}$. The above media was inoculated with a disc of 8 days old culture of $C$. indicum. fermentation was carried out at $28+2{ }^{\circ} \mathrm{C}$ and $200 \mathrm{rpm}$ on a rotary shaker incubator for 12 days. After incubation, filtrates were obtained and used for enzyme assay.

\section{Enzyme assay}

Keratinase production was measured by the method of Gupta and Ramnani (2004). The test tube containing 1 $\mathrm{ml}$ of enzyme $4 \mathrm{ml}$ of glycine- $\mathrm{NaOH}$ buffer and $20 \mathrm{mg}$ of chicken feather (collected from poultry shop) were incubated at $60^{\circ} \mathrm{C}$ for $60 \mathrm{~min}$. $4 \mathrm{ml}$ of $5 \%(\mathrm{w} / \mathrm{v}) \mathrm{TCA}$ were added to terminate the reaction and incubated 60 $\mathrm{min}$ at room temperature. Feathers were removed by filtration. Control was prepared similarly except $1 \mathrm{ml}$ of $5 \%$ TCA and $3 \mathrm{ml}$ of Buffer were added. Keratinase activity was recorded at $280 \mathrm{~nm}$ against the control using UV-VIS spectrophotometer. An increase 0.01 in absorbance was considered as 1 unit of enzyme activity per $\mathrm{ml}$.

\section{Purification of enzyme}

\section{Ammonium sulphate precipitation}

The enzyme was purified by the method of Suntornsuk et al. (2005) and Shivakumar et al., (2012). 0-20\% $(5.49 \mathrm{~g})$ ammonium sulphate was added to $50 \mathrm{ml}$ of crude enzyme. After precipitation, the pellet was collected and centrifuged at $5000 \mathrm{rpm}$ for $25 \mathrm{~min}$. in cooling centrifuge. The subsequent saturation was done 20 $-40 \%, 40-60-\%, 60-80 \%, 80-100 \%$. The precipitates were dissolved in $0.05 \mathrm{M}$ glycine- $\mathrm{NaOH}$ buffer $(\mathrm{pH} \mathrm{10})$. After precipitation enzyme was desalted by using Himedia dialysis membrane-50. Dialysis membrane was regenerated by dipping in a solution of $2 \%$ sodium bicarbonate solution and $0.5 \%$ EDTA boiled for $10 \mathrm{~min}$. after filling the enzyme membrane was left in glycine $\mathrm{NaOH}$ buffer for 3-4 hours for desalting.

\section{Gel filtration chromatography}

Dialyzed enzyme was purified with Sephadex G-75 (mol. wt 1000-5000) column chromatography. The enzyme solution was run into column according to $6 \mathrm{ml} / \mathrm{hr}$ flow rate with $.05 \mathrm{M}$ glycine $\mathrm{NaOH}(\mathrm{pH} 10)$ buffer and fractions of $3 \mathrm{ml}$ were collected. The absorbance of the fractions was observed at $280 \mathrm{~nm}$.

\section{Affinity chromatography}

The collected fraction was applied to diethylaminoethyl (DEAE) Sepharose column. Enzyme was run into a column according to $6 \mathrm{ml} / \mathrm{hr}$ flow rate with $0.05 \mathrm{M}$ glycine- $\mathrm{NaOH}$ buffer $(\mathrm{pH} 10)$. The column was eluted with $0.025 \mathrm{M}$ glycine- $\mathrm{NaOH}$ buffer $(\mathrm{pH} 7$ with flow rate $12 \mathrm{ml} /$ $\mathrm{hr}$. Fraction of $3 \mathrm{ml}$ was collected and absorbance was recorded at $280 \mathrm{~nm}$.

\section{Enzyme characterization \\ Temperature characterization}

An enzyme assay was done at various temperatures to find the optimum temperature for keratinase activity. The temperature should be between 30 and $70^{\circ} \mathrm{C}$ at $\mathrm{pH}$ 10. The Keratinase assay conditions were same as enzyme assay. 
Kumar, J. and Mahal, S. / J. Appl. \& Nat. Sci. 13(2), 744 - 751 (2021)

\section{pH characterization}

Using $0.1 \mathrm{M}$ phosphate buffer $(6-8 \mathrm{pH})$ and $0.05 \mathrm{M}$ glycine- $\mathrm{NaOH}(\mathrm{pH} 9-11)$, the effect of $\mathrm{pH}$ on keratinase was determined. The other cultural conditions were the same as enzyme assay.

\section{Substrate characterization}

The substrate BSA, feather, keratin powder, keratin azure were added $20 \mathrm{mg}$ in each test and enzyme assay was performed.

\section{RESULTS AND DISCUSSION}

\section{Isolation and screening of keratinophilic fungi}

The keratinophilic fungi grown on the feather is shown in Fig $1 \mathrm{a}$ and $\mathrm{b}$. The Isolate (1026) keratinophilic fungi was identified as $C$. indicum. It was deposited in the Departmental laboratory of Dolphin PG College of Science \& Agriculture, Chunnikalan $(\mathrm{Pb})$ as JK14 and sent to National Fungal Culture Collection of India, Pune accession number. $C$. indicum showed the clearing zone tested on skimmed milk agar plates for its keratinase enzyme activity (Fig. 1c).

C. indicum attained $35-40 \mathrm{~mm}$ diameter growth in 8 days on PDA, cultured in $99 \mathrm{~mm}$ Petri plates. Powdery white thin denser and up to $2 \mathrm{~mm}$ high at the center, margin defined, regular, fimbricate, reverse cream coloured (Fig. 2a). Hyphae were hyaline, smooth and thinwalled and rarely branched, while sterile more frequently branched, when aerial hyphae fertile and infertile, 1.5 $-5.0 \mu \mathrm{m}$ wide, submerged hyphae mostly sterile, straight $1-4 \mu \mathrm{m}$ wide, the narrower often contorted. Terminal and lateral conidia sessile or on short protrusions of slightly swollen lateral branches, solitary, infrequently subtended by alternative conidium, subhyaline smooth or slightly echinulate, thin walled, ovoid to ellipsoid, 1

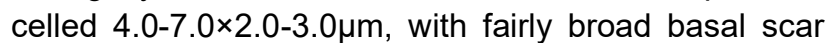
(1-1.5 $\mu \mathrm{m})$. Intercalary conidia less abundant, solitary sub hyaline (Fig. 2 b-h).

\section{FTIR analysis}

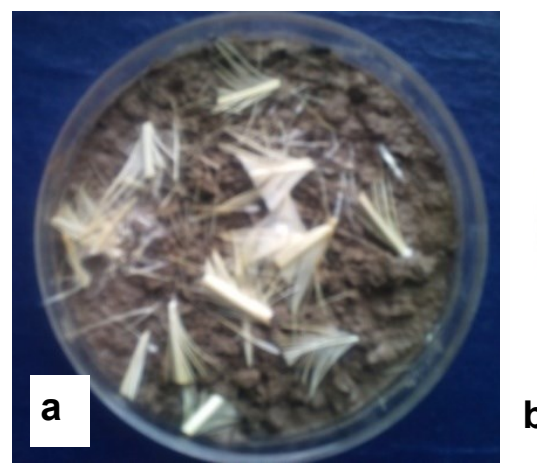

The feathers were degraded by $C$. indicum in submerged state fermentation (Feg. 4). Degraded feathers showed the presence of $\mathrm{COOH}$ and $\mathrm{NH}_{2}$ group in FTIR analysis. After comparison of samples, it was found that the characteristic peaks were similar to each other and comparable with other studies in the case of keratin extraction from the chicken feather waste by application of reducing agent I-cysteine (Ma et al., 2016). Band region found between $3500-3200 \mathrm{~cm}^{-1}$ was attributed to the starching vibration of $-\mathrm{O}-\mathrm{H}-$ and $-\mathrm{N}-\mathrm{H}$ amide band (Pavia et al., 2008) and appeared in the range between 3000-2800 were related to symmetrical $\mathrm{CH}_{3}$ stretching vibration. The strong band was attributed to -CO- stretching (amide I), which occurred in the range of $1700-1600 \mathrm{~cm}^{-1}$ (Mohanty et al., 2005). The band (amide II) in the range of $1580-1480 \mathrm{~cm}^{-1}$ was for $-\mathrm{N}-\mathrm{H}$ banding and $\mathrm{C}-\mathrm{H}$ stretching (Eslahi et al., 2013). The band associated with amide III observed weak between $1300-1220 \mathrm{~cm}^{-1}$ which was derived from $\mathrm{C}-\mathrm{N}$ stretching C-O- bond band and C-C stretching (Vasconcelos et al., 2008). In the sulphoxide region at $1073 \mathrm{~cm}^{-1}$ the band corresponding to S-O was observed for degraded feathers (Fig. 3). Untreated feather had a band with low intensity and was poorly visible (Kumar and Yadav, 2020), while in degraded feather, the intensity of the band was high. The band between $750-600 \mathrm{~cm}^{-1}$ was related to $-\mathrm{N}-\mathrm{H}$ out of plane banding.

\section{Characterization of purified enzyme Temperature characterization}

The enzyme after partial purification was subjected to enzyme assay. The purified enzyme by Sephadex G-7 column and DEAE sepharose column showed maximum enzyme activity of $69.2 \mathrm{U} / \mathrm{ml}$ at temperature $50^{\circ} \mathrm{C}$ and $61.9 \mathrm{U} / \mathrm{ml}$ was observed at temperature $60^{\circ} \mathrm{C}$ (Fig. 5 $\& 6)$.

\section{pH characterization}

Enzyme assay of Sephadex G-75 and DEAE cellulose column purified enzyme done for $\mathrm{pH}$ characterization at

Fig. 1 a. Growth of C. indicum on feather baits, b. C. indicum degraded feather, c. clearing zone by produced by $C$. indicum on skimmed milk agar. 


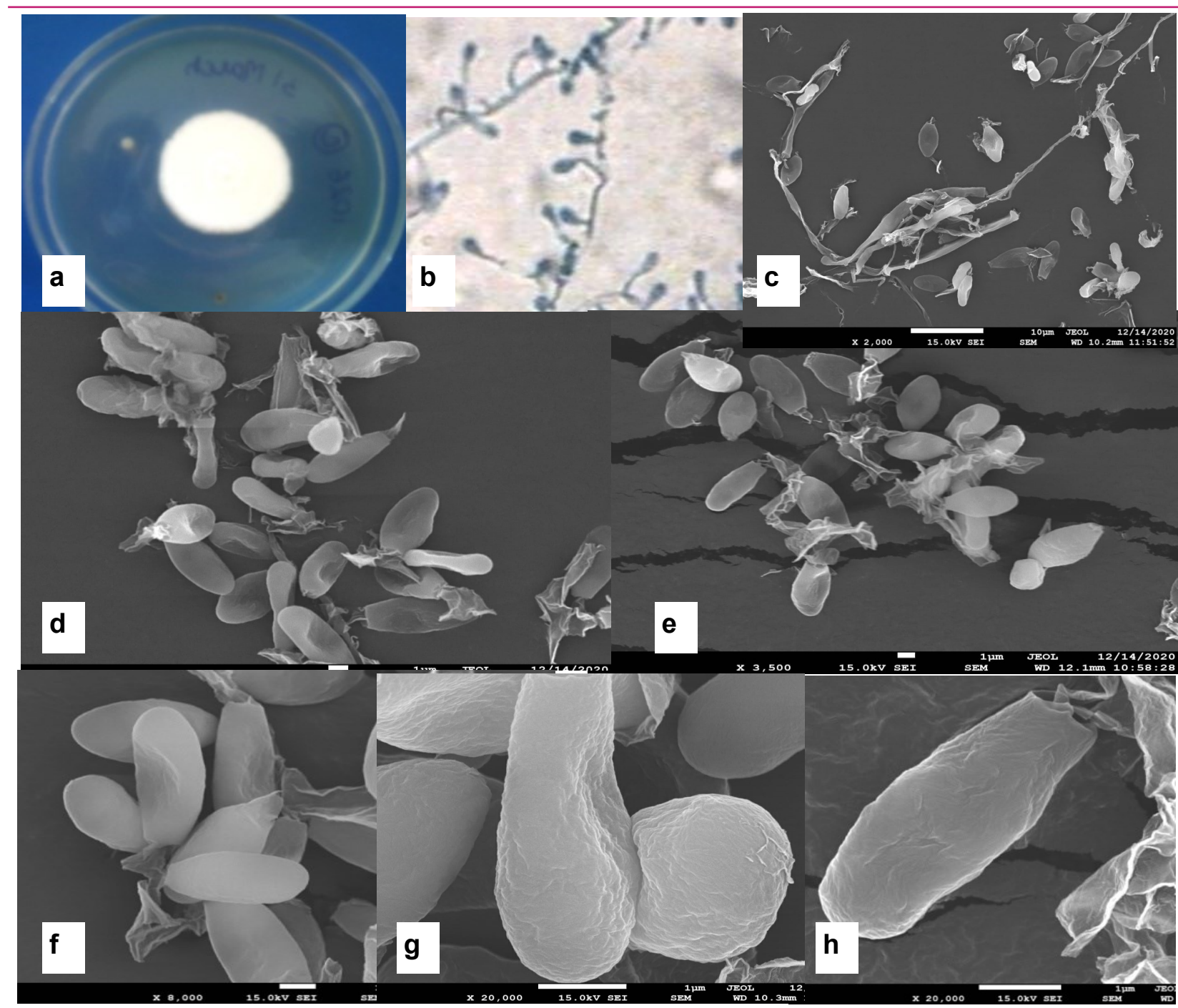

Fig. 2. a. Growth of C. indicum on Potato Dextrose Agar, b. Conidia 1000X, c. SEM of C. indicum Hyphae \& terminal conidia (10 $\mu \mathrm{m}$ 2000X). d-e. $1 \mu \mathrm{m}$ 3500X, f. $1 \mu \mathrm{m}$ 10000X g-h. Conidia $1 \mu \mathrm{m}$ 20000X.

incubation temperature of $50^{\circ} \mathrm{C}$. showed that maximum enzyme activity of $69.2 \mathrm{U} / \mathrm{ml}$ was at $\mathrm{pH} 10$ and $61.9 \mathrm{U} /$ $\mathrm{ml}$ was at $\mathrm{pH} 10$ respectively (Fig. 7 and 8 ).

\section{Substrate characterization}

The maximum enzyme activity of $289.1 \mathrm{U} / \mathrm{ml}$ was observed with keratin powder as substrate and minimum enzyme activity $67.1 \mathrm{U} / \mathrm{ml}$ was observed with keratin azure with enzyme purified with gel filtration. The maximum enzyme activity of $262.9 \mathrm{U} / \mathrm{ml}$ was observed with keratin powder and minimum enzyme activity $56.5 \mathrm{U} / \mathrm{ml}$ was observed with keratin azure with enzyme purified with affinity chromatography (Fig. 9 A \& B).

Comparison of keratinolytic activities was difficult due to different conditions applied during experimentation as keratin substrate variety, diverse chromatography column and microorganism used in study. Gradisar et al., (2005) compared optimim pH for keratinases activity from Paecilomyces marquandii, Doratomyces microspores and $A$. flavus and recorded $\mathrm{pH} 8,8$ and 11 re- spectively. Kim (2007) studied Aspergillus fumigatus and purified keratinase gave maximum activity at $\mathrm{pH} 8$ and temp $45^{\circ} \mathrm{C}$. However, enzyme keratinase was active at $30-7^{\circ} \mathrm{OC}$ temperature and at $\mathrm{pH}$ 7-10. Vigneshwaran et al. (2010) reported activity of

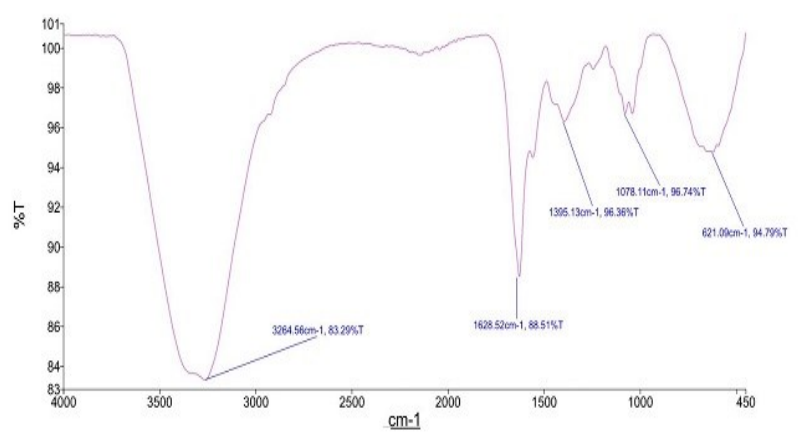

Fig. 3. FTIR spectra of C. indicum degraded feather. 


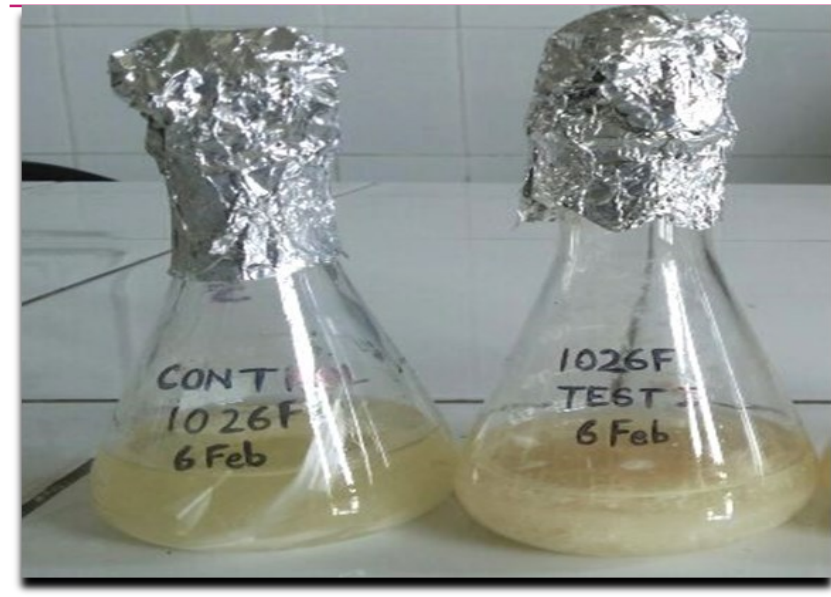

Fig. 4. Feather degradation in submerged state fermentation (Control \& Test).

keratinase enzyme from Bacillus licheniformis was characterized for optimum $\mathrm{pH} 7$, temp $60^{\circ} \mathrm{C}$. Nayaka and Vidyasagar (2013) observed $\mathrm{pH} 7$ as optimum for keratinase activity from Streptomyces albus while $B$. megaterium observed maximum keratinase activity at optimum $9.0 \mathrm{pH}$ and $50^{\circ} \mathrm{C}$ temperature (Saibabu et al., 2013). Poopathi et al., (2014) obtained 2.3-time purifi-

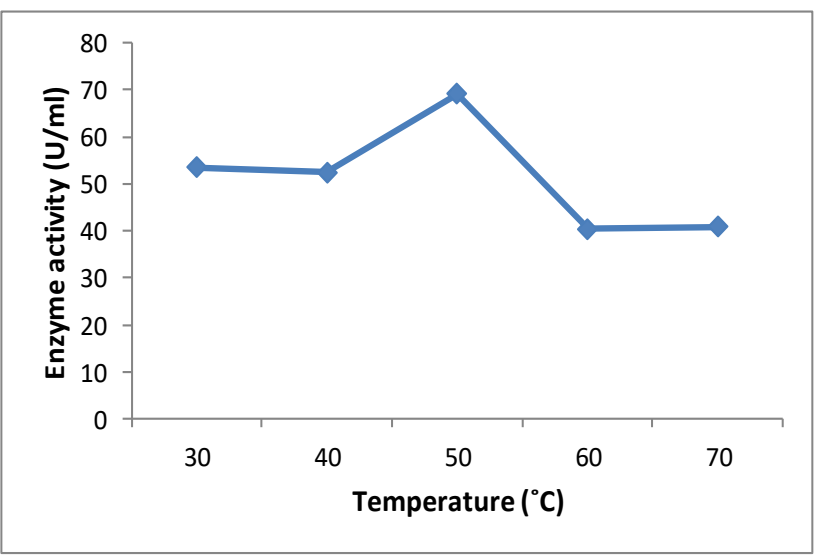

Fig. 5. Temperature activity of pure keratinase Sephadex G-75.

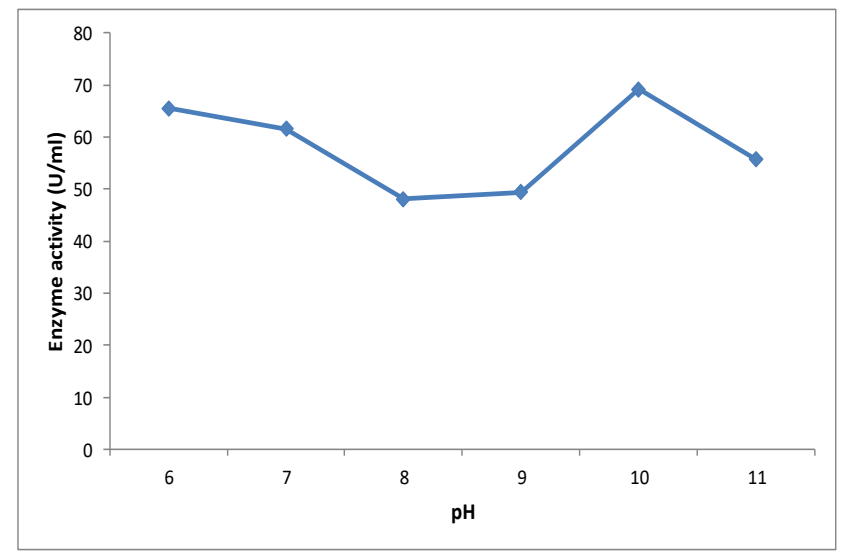

Fig. 7. $\mathrm{pH}$ activity for enzyme obtained from Sephadex G-75 cation in ammonium sulphate while 11.68-fold with sephacryl S-200 column while in present study $48.03 \%$ recovery of enzyme was recorded after DEAE sepharose column chromatgrapgy which was slightly higher than $30 \%$ observed by Lee et al. (1987) for Microsporum canis. Veerapura et al. (2019) observed optimum keratinase activity at $\mathrm{pH} 7$ and temperature of $35^{\circ} \mathrm{C}$ by Serratia sp. Hamiche et al. (2019) obtained keratinase enzyme KERZT-A was ideally dynamic at $\mathrm{pH} 6.5$ and $50^{\circ} \mathrm{C}, \mathrm{KERZT}-\mathrm{B}$ appeared ideal at $\mathrm{pH} 8$ and $60^{\circ} \mathrm{C}$. The keratinase from Bacillus sp. showed optimum activity at $\mathrm{pH} 8$ and $60-80^{\circ} \mathrm{C}$ temperature (Nnolim and Nwodo, 2020). Results obtained in the present study were in accordance with the study of Gradisar et al. (2005) and Kim (2007) Saibabu et al. (2013) as optimum of $\mathrm{pH} 10$ and temperature of $50-60^{\circ} \mathrm{C}$ and were in range. There was always some variation due to bacterial and fungal isolates used for enzyme production. In present study, keratin powder substrate showed maximum enzyme activity of $289.1 \mathrm{U} / \mathrm{ml}$ as substrate while using a feather as substrate enzyme activity showed $61.9 \mathrm{U} / \mathrm{ml}$. It was observed that the small size of the keratinous substrate was better for enzyme activity due

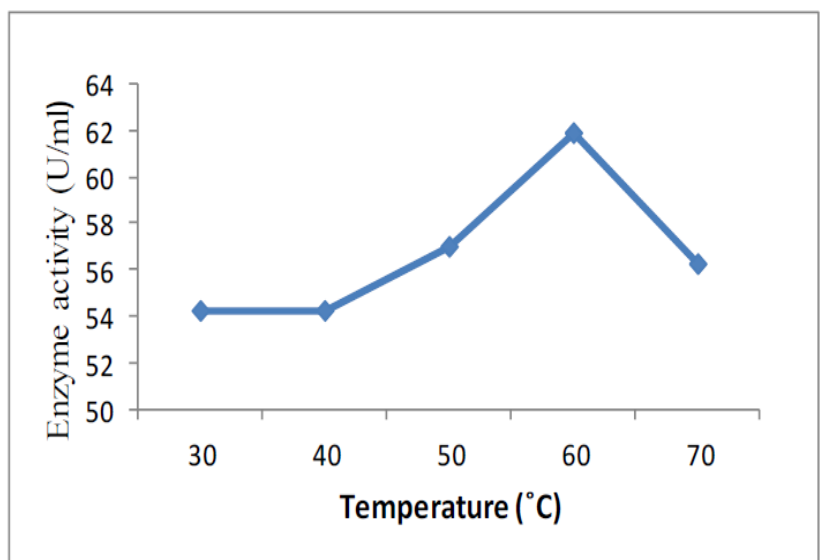

Fig. 6. Temperature activity of enzyme obtained from $D E A E$ Sepharose column.

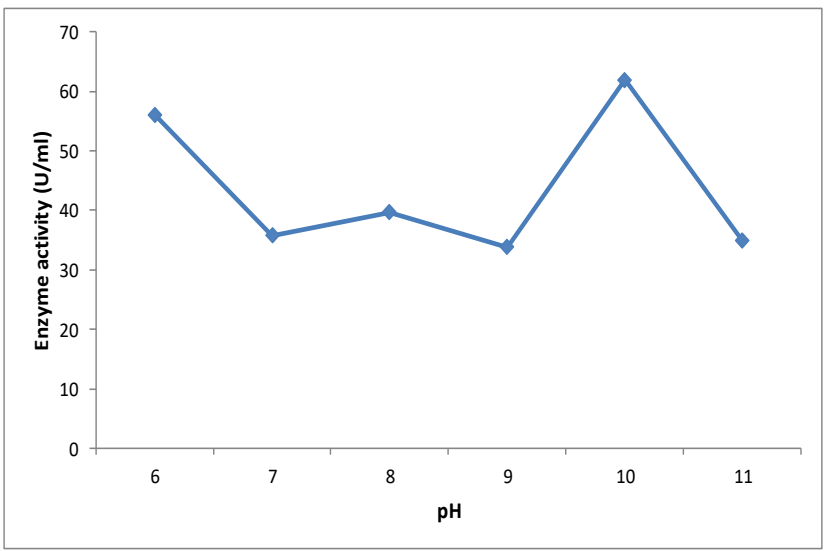

Fig. 8. Enzyme activity at $p H$ purified by DEAE Sepharose column. 

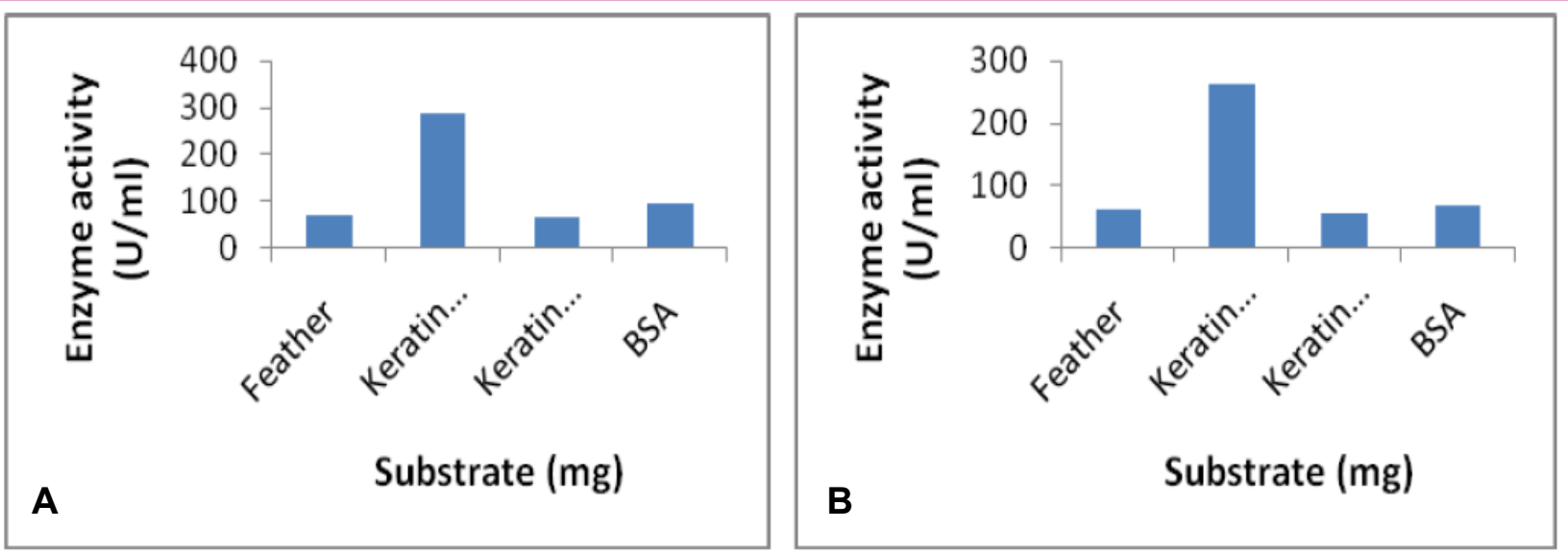

Fig. 9 A \& B. Showing substrate activity (A. After Sephadex G-75, B. After DEAE Sepharose column).

to the powder state of matter always provide more surface area for enzyme-substrate reactions.

\section{Conclusion}

The Isolate of $C$. indicum was found to be the most promising Isolate for keratinase production and feather degradation. The maximum keratinase activity was observed at $50^{\circ} \mathrm{C}$, at $\mathrm{pH} 10$. Purified keratinase enzyme degraded a diverse substrate as keratin powder, keratin azure and feathers, BSA protein although the maximum activity $289.1 \mathrm{U} / \mathrm{ml}$ with keratin powder indicate that small substrate size is optimum for maximum degradation. The fungus $C$. indicum could be used to produce the enzyme keratinase, which has potential application in prion degradation, enhancing the nutritional value of animal feed containing keratin, development of keratin waste biofertilizers and keratin waste utilization.

\section{Conflict of interest}

The authors declare that they have no conflict of interest.

\section{REFERENCES}

1. Allpress, J.D., Mountain, G. \& Gowland P.C. (2002). Production, purification and characterization of an extracellular keratinase from Lysobacter NCIMB 9497. Letters in Applied Microbiology, 34, 337-342. doi: 10.1046/j.1472765x.2002.01093.x.

2. Anitha, T.S. \& Palanivelu, P. (2012). Production and characterization of keratinolytic proteases from the fungus Aspergillus parasiticus. International Journal of Research in Biological Sciences, 2(2), 87-93.

3. Benedek, T. (1962). Fragmenta mycologia I. Some historical remarks on the development of "hair baiting" of TomaKarling-Vanbreuseghem (The To-Ka-Va hair baiting method). Mycopathol Mycol Appl. 16:104-106.

4. Cai, C., Ji-shuang, C., Jiong-jiong, Q., Yun, Y. \& Xiaodong, Z. (2008). Purification and characterization of keratinase from a new Bacillus subtilis strain. Journal of Zhejiang University, 9 (9):713-720. doi: 10.1631/
jzus.B0820128

5. De Toni, C.H., Richter, M.F., Chagas, J.R., Henriques, J.A. \& Termignoni, C. (2002). Purification and characterization of an alkaline serine endopeptidase from a featherdegrading Xanthomonas maltophilia strain. Can J Microbiol., 48:342-348.

6. Eslahi, N., Dadashian, F. \& Nejad, N.H. (2013). An investigation on keratin extraction from wool and feather waste by enzymatic hydrolysis. Prep Biochem. Biotechnol., 43:624-648. doi: 10.1080/10826068.2013.763826.

7. Esawy, M.A. (2007). Isolation and partial characterization of extracellular keratinase from a novel mesophilic Streptomyces albus AZA. Research Journal of Agriculture and Biological Sciences, 3(6):808-817. DOI: 10.108 0/10826068.2013.763826

8. Friedrich, A.B. \& Antranikian, G. (1996). Keratin degradation by Fervidobacterium pennavorans, a novel thermophilic anaerobic species of the order Thermotogales. Appl Environ Microbiol., 62:2875-2882. doi: 10.1128/ aem.62.8.2875-2882.1996.

9. Gradisar, H., Friedrich, J., Krizaj, I. \& Jerala, R. (2005). Similarities and specificities of fungal keratinolytic proteases: comparison of keratinase of Paecilomyces marquandii and Doratomyces microsporus to some known proteases. Appl Environ Microbiol., 71(7): 3420-3426. doi: 10.1128/ AEM.71.7.3420-3426.2005.

10. Gupta, R. \& Ramnani, P. (2006). Microbial keratinases and their prospective applications: an overview. Appl. Microbial Biotechnology, 70(1):21-33. https:// doi.org/10.1007/s00253-005-0239-8.

11. Hamiche, S., Mechri, S., Khelouia, L., Annane, R., El Hattab, M., Badis, A. \& Jaouadi, B. (2019). Purification and biochemical characterization of two keratinases from $\mathrm{Ba}$ cillus amyloliquefaciens S13 isolated from marine brown alga Zonaria tournefortii with potential keratinbiodegradation and hide-unhairing activities. Int. J. Biol. Macromol., 122(1):758-769. doi: 10.1016/ j.ijbiomac.2018.10.174.

12. Kainoor, P.S. \& Naik, G.R. (2010). Production and characterization: of feather degrading keratinase from Bacillus sp. JB 99. Indian journal of Biotechnology, 9:384-390.

13. Kanchana, R. (2012). Farm waste recycling through microbial keratinases. Journal of Applied Sciences in Environmental Sanitation, 7 (2): 103-108.

14. Kim, J.D. (2007). Purification and Characterization of a 
Kumar, J. and Mahal, S. / J. Appl. \& Nat. Sci. 13(2), 744 - 751 (2021)

Keratinase from a Feather-Degrading Fungus, Aspergillus flavus Strain K-03. Microbiology, 35(4):219-225. doi: 10.4489/MYCO.2007.35.4.219. doi: 10.4489/MYCO.200 7.35.4.219

15. Kumar, J. \& Kushwaha, R.K.S. (2014). Screening of fungi efficient in feather degradation and keratinase production. Arch. Appl. Sci. Res., 6(1): 73-78.

16. Kumar, J. \& Kushwaha, R.K.S. (2012). Optimization of media composition for keratinase production on feather by Acremonium strictum RKS1. Advances in Applied Science Research, 3(5):3233-3243.

17. Kumar, J., Kumar, P. \& Kushwaha, R.K.S. (2020). Recycling of chicken feather protein into compost by Chrysosporium indicum JK14 and their effect on the growth promotion of Zea mays. Plant Cell Biotechnology and Molecular Biology, 21(37\&38): 75-80.

18. Kumar, J. \& Yadav, R. (2020). Keratinolysis of human hair and chicken feather by nondermatophytic keratinophilic fungi isolated from soil. Journal of Applied and Natural Sciences, 12(4):568-574. https://doi.org/10.31018/ jans.v12i4.2398.

19. Kumar J., Kumar P. \& Kushwaha RKS (2021). Significance of keratinophiles in biofertilizer development from keratinous waste: upcoming perspective. In: Biofertilizers Vol. 1, 1st Edition (eds. Rakshit A, Meena V, Singh HB, Singh AK, Pahihar M). (Elesvier). pp. 95-101. https:// doi.org/10.1016/B978-0-12-821667-5.00006-3.

20. Kumari, M. \& Kumar J. (2020). Chicken feather waste degradation by Alternaria tenuissima and its application on plant growth. Journal of Applied and Natural Sciences, 12(3): 411-414. https://doi.org/10.31018/jans.v12i3.2345

21. Lee KH., Park K.K., Park S.H. \& Lee J.B. (1987). Isolation purification and characterization of keratinolytic proteinase from Microsporum canis. 28(2): 131-137.

22. Lin, X., Inglis, G.D., Yanke, L.J. \& Cheng, K.J. (1999). Selection and characterization of feather-degrading bacteria from canola meal compost. $J$ Indust Micro \& Biotech., 23:149.

23. Langeveld, J.P.M. \& Wang, J., Wiel, DFMV., Shih, G.C., et al. (2003). Enzymatic degradation of prion protein in brain stem from infected cattle and sheep. The Journal of infectious diseases, 188:1782-1789. doi: $10.1086 / 379664$

24. Ma, B., Qiao, X., Hou, X. \& Yang, Y. (2016). Pure keratin membrane and fibers from chicken feather. Int. J. Biol. Macromolecules, 89:614-621. doi: 10.1016/j.ijbioma c.2016.04.039.

25. Mehta, R.S., Jholapara, R.J. \& Sawant, C.S. (2014). Isolation of a novel feather degrading bacterium and optimization of its cultural conditions for enzyme production. International Journal of Pharmacy and Pharmaceutical Sciences, 6(1):194-201.

26. Mohanty, A.K., Misra, M. \& Drzal, L.T. (2005). Natural Fibers, Biopolymers and Bio Composites, Ist Edition, CRC press, pages 896 .

27. More, S.S., Sridhar, D.L., Prakash, S.N., Vishwakarma, J. \& Umashankar S. (2013). Purification and properties of novel fungal alkaline keratinase from Cunnighamella echinulata. Turkish J. of Biochemistry, 38(1): 68-74.

28. Nnolim, N.E. \& Nwodo, U.U. (2020). Bacillus sp. CSK2 produced thermostable alkaline keratinase using agrowastes: keratinolytic enzyme characterization. BMC Bio- technol., 20:65 doi.org/10.1186/s12896-020-00659-2

29. Onifade, A.A., Al-Sane, N.A., Al-Musallam, A.A. \& AlZarban, S. (1998). A Review: Potentials for biotechnological applications of keratin-degrading microorganisms and their enzymes for nutritional improvement of feathers and other keratins as livestock feed resources. Bioresour Techno., 66: 1-11.

30. Pavia, D.L., Lampman, G.M., Kriz, G.S. \& Vyvyan, J.A. (2008). Introduction to spectroscopy, fifth edition, Cengage learning, USA, pages 786 .

31. Poopathi, S., Thirugnanasambantham, K., Mani, C., Lakshmi, P.V. \& Ragul, K. (2014). Purification and characterization of keratinase from feather degrading bacterium useful for mosquito control-a new report. Trop. Biomed., 31(1):97-109. PMID: 24862049.

32. Ramnani, P. \& Gupta, R. (2004). Optimization of medium composition for keratinase production on feather by Bacillus licheniformis RGI using statistical methods involving reponse surface methodology. Biotechnol. Appl. Biochem., 40:191-196. doi: 10.1042/BA20030228.

33. Ramnani, P., Singh, R. \& Gupta, R. (2005). Keratinolytic potential of Bacillus licheniformis RG1: Structural and biochemical mechanism of feather degradation. Can $J$ Microbiol., 51(3):191-196. doi: 10.1139/w04-123.

34. Raju, K.C., Neogi, U., Saumya, R. \& Goud, N.R. (2007). Studies on extracellular enzyme keratinase from Dermatophyte Microsporum gypseum. International Journal of Biological Chemisry. 1(3): 174-178.

35. Riffel, A. \& Brandelli, A. (2006). Keratinolytic bacteria isolated from feather waste. Brazilian Journal of Microbiology, 37, 395-399. https://doi.org/10.1590/S1517-8382200 6000300036

36. Saibabu, V., Niyonzima F.N. \& More S.S. (2013). Isolation, partial purification and characterization of keratinase from Bacillus megaterium. International Research Journal of Biological Sciences, 2(2):13-20.

37. Schrooyen, P.M.M., Dijkstra. P.J., Oberthur, R.C., Bantjes, A. \& Feijen, J. (2001). Partially carboxymethylated feather keratins and thermal and mechanical properties of films. Journal of Agricultural and Food Chemistry, 49:221230. doi: $10.1021 / \mathrm{jf9} 913155$.

38. Singh, C.J. (1997). Characterization of an extracellular keratinase of Trichophyton simii and its role in keratin degradation. Mycopathologia, 135: 13-16.

39. Sivakumar, T., Shankar, T. \& Ramasubramanian, V. (2012). Purification properties of Bacillus thuringiensis TS2 keratinase enzyme. American-Eurasian J. Agric. \& Environ. Science, 12(12):1553-1557.

40. Suntornsuk, W., Tongjun, J., Onnim, P., Ayama, H. \& Ratanakanokchai, K. (2005). Purification and characterization of keratinase from a thermotolerant feather degrading bacterium. World Journal of Microbiology \& Biotechnology, 21:1111-1117.

41. Vasconcelos, A., Fredid, G. \& Cavaco-Paulo, A. (2008). Biodegradable materials based on silk fibroin and keratin. Biomacromolecules, 1299-1305. doi: 10.1021/ bm7012789.

42. Vigneshwaran, C., Shanmugam, S. \& Sathish, K.T. (2010). Screening and characterization of keratinase from Bacillus licheniformis isolated from Namakkal poultry farm. Researcher, 2(4):89-96.

43. Veerapura, N.Y.M., Veerapura, N.M. \& Mahesh, M. 
Kumar, J. and Mahal, S. / J. Appl. \& Nat. Sci. 13(2), 744 - 751 (2021)

(2019). Production and purification of keratinase enzyme from Serratia sp. Isolated from poultry waste. Journal of Applied Science, 19:789-796.DOI: 10.3923/jas.2019.7 89.796.
44. Ya-peng, C., Xi, F.H., Yang, J., Lu, J.H. \& Qian, S.J. (2007). Screening for a new Streptomyces strain capable of efficient keratin degradation. J Environ Sci (China), 19 (9):1125-8. doi: 10.1016/s1001-0742(07)60183-1 